\title{
Morphological divergence of seedlings Calophyllum brasiliense cambes collected in São Paulo and Tocantins
}

\author{
Rodrigues-Nascimento, Ildon ${ }^{1}$; Pereira da Silva, Gândida ${ }^{1}$; Pascual-Reyes, Irais Dolores ${ }^{{ }^{*}}$; Torquato-Tavares, Aline ${ }^{1}$; \\ Nonato da Silva, Edilson ${ }^{1}$; Vaz de Melo, Aurélio ${ }^{1}$ \\ ${ }^{1}$ Universidad Federal de Tocantins (UFT)-Campus Gurupi, Brasil. Rua Badejós, chácaras 69 a 72, Lote 7 , \\ S/N, Jardim Sevilha, CEP: 77404-970, Gurupi-Tocantins, Brasil. \\ * Corresponding author: irais121@hotmail.com
}

Citation: Rodrigues-Nascimento, I., Pereira da Silva, C., Pascual-Reyes, I. D., TorquatoTavares, A., Nonato da Silva, E., \& Vaz de Melo, A. (2021). Morphological divergence of seedlings Calophyllum brasiliense Cambes collected in São Paulo and Tocantins. Agro Productividad, 14(\#). https://doi.org/10.32854/ agrop.v14i7.1869

Editor in Chief: Dr. Jorge Cadena Iñiguez

Estimated publication date: August 2021

This work is licensed under a Creative Commons Attribution-Non-Commercial 4.0 International license.

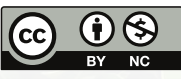

\begin{abstract}
Objective: The objective was to quantify the morphological diversity of Calophyllum brasiliense Cambes from four municipalities of the State of Tocantins employing morphological characteristics, to strengthen information on conservation and future breeding of the species.

Methodology: Seeds were collected from four municipalities in the State of Tocantins and one in the State of São Paulo. The following were evaluated: plant height, stem diameter, root length, number of leaves, leaf area, root dry mass, shoot dry mass, total dry mass, and Dickson's quality index. The data were subjected to univariate analysis of variance, Tocher grouping method, and UPGMA, obtaining a dendrogram through the generalized Mahalanobis distance.

Results: The results showed a statistical difference of 1 and 5\% probability. Dueré stood out in stem diameter $(5.52 \mathrm{~mm})$, Sandolandia in height $(34.84 \mathrm{~cm})$ and root length $(42.13 \mathrm{~cm})$. Formoso stood out in the number of leaves (34 leaves). Lagoa da Confusão in leaf area $\left(856.28 \mathrm{~cm}^{2}\right)$ and São Paulo in root dry mass (16.20 g), shoot dry mass $(12.38 \mathrm{~g})$, total dry mass $(16.20 \mathrm{~g})$, and Dickson's quality index (1.57).

Implications: Variations in morphological characteristics can be used as a tool for genetic studies of guanandi progeny according to their similarity and/or differences.

Conclusions: The morphological divergence evidenced that among the five studied areas it is possible to direct the collection of seeds to subsidize conservation strategies and future breeding of the species.
\end{abstract}

Keywords: Calophyllum brasiliense, characteristics, conservation, genetics.

\section{INTRODUGTION}

Calophyllum brasiliense Cambess is a species native to Brazil, known as guanandi, and belongs to the genus Calophyllum that comprises approximately 190 species, only eight of them occur in Central and South America (Soerianegara and Lemmens, 1993). It occurs from Mexico to South America, always in plains with temporary floods (Carvalho, 2003). Guanandi is considered climatic because due to abundant regeneration in the shade and is native to the Amazon and Cerrado regions (second largest Brazilian biome). The Calophyllum genus has multiple applications since the bark of the tree produces excellent- 
quality wood, and oil can be extracted from the seeds. This species can be used as an alternative to substitute mahogany and cedar that have problems with the shoot borer (Hypsipyla grandella), a pest that makes commercial cropping of both unfeasible (Wrege et al., 2017). Furthermore, it is currently becoming highly relevant due to its high medicinal potential, with various pharmacological uses due to its antidepressant, antioxidant, and antimicrobial effects (Bernabé et al., 2015). C. brasiliense is on the list of Amazonian tropical forest species that should be considered within in situ and ex situ genetic resource conservation programs (Tropical Flora Reflorestadora, 2014).

The floodplains are among the ecosystems that suffer the most disturbances, either due to the presence of relatively fertile and humid soils, ideal attributes for agriculture and pasture formation or due to the high diversity of species that serve as a source of wood and non-wood forest products. (Reis et al., 2009). The State of São Paulo has a large marginal area for the commercial cultivation of guanandi, being a transition region for the Cerrado and total precipitation is low, which can influence the yield of commercial crops (Wrege $e t$ al., 2017).

In the State of Tocantins, the floodplains have been widely exploited by agriculture, with cropping of rice, soybeans, watermelons, among others. With all this, many tree populations have already been reduced or eliminated, as a direct consequence, there is a reduction in the size and isolation of the populations, which will result in inbreeding and genetic drift (Botrel et al., 2006). In addition, the state also presents marginal conditions similar to those of São Paulo for the production of guanandi, however, there are no studies that report these facts.

The conservation of native species and, in general, of natural resources as a whole, serves to maintain the representativeness of the species, conserve natural resources to mitigate human and environmental catastrophes, preserve the maximum genetic variability, and form ecological corridors, being its use one of the viable alternatives for the genetic resources conservation.

Quantifying the genetic diversity of guanandi through morphological characteristics can serve as a model for the generation of conservation programs for the species, in addition to guiding material collection programs for germplasm banks and seedling production for reforestation programs.

Currently, the existing knowledge about guanandi is insufficient to indicate it as an alternative to pine and eucalyptus, although its future seems to be promising since more advanced research is still necessary, in which cultural techniques are developed that allow greater production at the lowest cost (Wrege et al., 2017).

The objective was to quantify the morphological divergence of Calophyllum brasiliense Cambess. from four municipalities of the State of Tocantins employing morphological characteristics, to strength the information for conservation programs and future breeding of the species.

\section{MATERIAL AND METHODS}

The study was carried out at the Experimental Station of the Gurupi University Campus, Federal University of Tocantins (UFT), located at $11^{\circ} 44^{\prime} 42^{\prime \prime}$ south latitude, 
49 03' 05" west longitude, and 276 meters above sea level. According to Köppen (1948), the regional climatic classification is of the type B1wA'a 'humid with moderate hydric deficiency. The average annual temperature is $29.5^{\circ} \mathrm{C}$, with an average annual rainfall of $1,804 \mathrm{~mm}$. Tree seeds were collected in four municipalities of the State of Tocantins: Formoso do Araguaia, Dueré, Sandolandia, and Lagoa da Confusão.

The climate of this region is characterized by the Aw type according to Köppen (1948), defined as tropical humid with a rainy season in summer and dry in winter, being the month with the most rain January, and the driest August. As a comparison control, seeds of mother plants from Piracicaba-SP were used, with a Cwa type climate (altitude tropical), at 554 meters above sea level, mean annual rainfall of $1,328 \mathrm{~mm}$ and minimum mean annual temperature of $14.8^{\circ} \mathrm{C}$ and maximum of $28.2^{\circ} \mathrm{C}$.

The seeds were collected from the fruits of mother plants that naturally detached from healthy, vigorous, and fully mature trees. The areas where the collections were performed in the state of Tocantins were georeferenced and the data was used to represent the geographic locations during 2017.

To obtain the seedlings, the seeds were removed from the pulp and mechanically scarified to break dormancy. The sowing was carried out in beds composed of coarse sand. The seedlings were transplanted when reached $10 \mathrm{~cm}$ high to polyethylene bags with a capacity of $2 \mathrm{~kg}$ of substrate, where they remained until the end of the experimental period (120 days). Subsoil and tanned manure were used as substrates in a ratio of $2: 1(\mathrm{v} / \mathrm{v})$.

For the fertilization of the substrate, $150 \mathrm{~g}$ of $\mathrm{N}$ (urea) and $100 \mathrm{~g}$ of $\mathrm{K}_{2} \mathrm{O}$ (potassium chlorate) were applied for each $\mathrm{m}^{3}$ (Schorn and Formento, 2003). Four top-dressings were carried out every 30 days, in quantities of $3 \mathrm{~g}$ of $\mathrm{N}$ and $2 \mathrm{~g}$ of $\mathrm{K}_{2} \mathrm{O}$ for each plant. During the conduct of the experiment, soil moisture was maintained at field capacity with daily irrigation. The experimental design was completely randomized with five treatments (four treatments from the municipalities of Tocantins and one from São Paulo), with eight replications and 10 plants per plot.

At 120 days, the following morphological characteristics were evaluated: plant height (PH in $\mathrm{cm}$ ); stem diameter (SD in $\mathrm{mm}$ ) using a $0.001 \mathrm{~mm}$ precision digital caliper; root length $(\mathrm{RL}$ in $\mathrm{cm})$; number of leaves $(\mathrm{NL})$; leaf area $\left(\mathrm{FA}\right.$ in $\left.\mathrm{cm}^{2}\right)$; root dry mass $(\mathrm{RDM}$ in $\mathrm{g}$ ); shoot dry mass (SDM in g), total dry mass (TDM in $\mathrm{g}$ ), obtained in a forced air circulation oven at $60{ }^{\circ} \mathrm{C}$ until obtaining a constant mass, and Dickson's quality index (DQI), estimated with the equation:

$$
D Q I=\frac{T D M}{\frac{P H(\mathrm{~cm})}{D(\mathrm{~mm})}+\frac{S D M(\mathrm{~g})}{R D M(\mathrm{~g})}}
$$

The leaf area was determined with the use of known areas of cylindrical perforators, which were used to remove leaf discs. These leaf discs were removed from various parts of the leaves, packed in paper bags, and taken to a forced-air oven until they reached constant 
mass. The leaves that were not used were placed in another paper bag and were also taken to the oven for drying.

The leaf area was estimated from the relationships between the discs dry mass (DDM), the total disc area, the sum of the areas of all the discs (AD), and the total dry mass of the leaf samples used (DMLS), unused leaves, and discs (Oliveira et al., 2002).

The variance analysis was carried out with the estimation of the mean squares of each morphological characteristic. Their significance was verified by the $\mathrm{F}$ test, and the means were grouped by the Scott-Knott test $(\mathrm{p} \leq 0.05)(1974)$, using the statistical program Sisvar ${ }^{\circledR}$ version 5.5 (Ferreira, 2019).

The genetic divergence between the seedlings collected in the five areas was estimated using morphological data related to the initial seedlings development in the evaluation at 120 days. The variance analysis was performed, and the dissimilarity measures were determined according to the multivariate analysis model, which allowed obtaining the dissimilarity matrix, the residual covariance matrix, and the area means.

The Tocher grouping methods (Rao, 1952) and the UPGMA method (unweighted pair group method with arithmetic mean) were used to obtain a dendrogram using the generalized Mahalanobis distance (D2) as a dissimilarity measure. Singh's (1981) criterion was also used to quantify the relative contribution of these characteristics to the genetic divergence. The analyzes were carried out using the Genes ${ }^{\circledR}$ computer program (Cruz, 2016).

\section{RESULTS AND DISCUSSION}

There were significant differences for the characteristics of stem diameter, root length, leaf area, shoot dry mass, total dry mass, and Dickson's quality index, evidencing the significant differences between the origins of the seeds. However, there were no significant differences within the collecting areas for any of the characteristics evaluated. It is fundamental to note that evident when the genetic variability of this species is sought, the seed collections should be performed in different areas (Table 1).

The guanandi seedlings from Formoso do Araguaia and Sandolandia showed similarities in the characteristics of stem diameter, shoot dry mass, total dry mass, and dissimilarity with the seedlings of Lagoa da Confusão and São Paulo (Table 1). As for root length, no differences were observed between Formoso do Araguaia, Dueré, and Lagoa da Confusão, but they differed from those of Sandolandia and São Paulo. The seedlings from Sandolandia stood out among the other locations for root length, with a mean of $42.13 \mathrm{~cm}$.

No significant differences were detected for leaf area between the seedlings from Formoso do Araguaia and Sandolandia, however, they differed from the seedlings from Lagoa da Confusão and Sao Paulo. The Dueré seedlings were different from the four areas. Higher means for leaf area were found in the seedlings of Lagoa da Confusão and São Paulo, with means equal to $856.28 \mathrm{~cm}^{2}$ and $847.79 \mathrm{~cm}^{2}$, respectively.

As for the Dickson quality index, only the Formoso do Araguaia seedlings differed from the others, presenting the lowest mean (0.93). The seedlings from Dueré, Sandolandia, Lagoa da Confusão, and São Paulo presented the best DQI, standing out from the other seedlings those of São Paulo presenting higher means (1.57). 
Table 1. Summary of the analysis of variance and means of guanandi seedlings from the State of Tocantins and the State of São Paulo. Gurupi - TO. 2018.

\begin{tabular}{|c|c|c|c|c|c|}
\hline \multicolumn{6}{|c|}{ MS } \\
\hline Characters & \multicolumn{2}{|c|}{ Between Areas } & Residue & General mean & CV (\%) \\
\hline $\mathrm{SD}(\mathrm{mm})$ & \multicolumn{2}{|c|}{$2.43^{* *}$} & 0.13 & 5.04 & 7.13 \\
\hline $\mathrm{PH}(\mathrm{cm})$ & \multicolumn{2}{|c|}{$20.31^{\mathrm{ns}}$} & 11.09 & 32.29 & 10.31 \\
\hline $\mathrm{NL}$ & \multicolumn{2}{|c|}{$127.05^{\mathrm{ns}}$} & 49.78 & 28.85 & 24.46 \\
\hline $\mathrm{RL}(\mathrm{cm})$ & \multicolumn{2}{|c|}{$67.50 *$} & 20.71 & 37.56 & 12.12 \\
\hline $\operatorname{RDM}(\mathrm{g})$ & \multicolumn{2}{|c|}{$2.64^{\mathrm{ns}}$} & 1.03 & 3.10 & 32.88 \\
\hline $\mathrm{LA}\left(\mathrm{cm}^{2}\right)$ & \multicolumn{2}{|c|}{$42,1846.40 * *$} & $38,018.01$ & 621.78 & 31.36 \\
\hline $\mathrm{SDM}(\mathrm{g})$ & \multicolumn{2}{|c|}{$62.68 * *$} & 7.55 & 9.50 & 28.92 \\
\hline $\mathrm{TDM}(\mathrm{g})$ & \multicolumn{2}{|c|}{$79.95 * *$} & 8.16 & 12.60 & 22.67 \\
\hline DQI & \multicolumn{2}{|c|}{$0.43^{* *}$} & 0.06 & 1.28 & 20.26 \\
\hline \multicolumn{6}{|c|}{ Means } \\
\hline Gharacters & Formoso & Dueré & Sandolandia & $\begin{array}{l}\text { Lagoa da } \\
\text { Confusão }\end{array}$ & São Paulo \\
\hline $\mathrm{SD}(\mathrm{mm})$ & $5.34 \mathrm{a}$ & $5.52 \mathrm{a}$ & $5.46 \mathrm{a}$ & $4.44 \mathrm{~b}$ & $4.44 \mathrm{~b}$ \\
\hline $\mathrm{PH}(\mathrm{cm})$ & $31.40 \mathrm{a}$ & $32.89 \mathrm{a}$ & $34.84 \mathrm{a}$ & $31.17 \mathrm{a}$ & $31.17 \mathrm{a}$ \\
\hline NL & $34.56 \mathrm{a}$ & $24.43 \mathrm{a}$ & $29.43 \mathrm{a}$ & $25.75 \mathrm{a}$ & $30.06 \mathrm{a}$ \\
\hline $\mathrm{RL}(\mathrm{cm})$ & $36.46 \mathrm{~b}$ & $35.71 \mathrm{~b}$ & $42.13 \mathrm{a}$ & $34.89 \mathrm{~b}$ & $38.63 \mathrm{a}$ \\
\hline $\operatorname{RDM}(\mathrm{g})$ & $2.28 \mathrm{a}$ & $2.96 \mathrm{a}$ & $3.43 \mathrm{a}$ & $3.00 \mathrm{a}$ & $3.82 \mathrm{a}$ \\
\hline $\mathrm{LA}\left(\mathrm{cm}^{2}\right)$ & $358.77 \mathrm{c}$ & $612.99 \mathrm{~b}$ & $433.09 \mathrm{c}$ & $856.28 \mathrm{a}$ & $847.79 \mathrm{a}$ \\
\hline $\operatorname{SDM}(\mathrm{g})$ & $6.39 \mathrm{~b}$ & $9.08 \mathrm{~b}$ & $7.28 \mathrm{~b}$ & $12.38 \mathrm{a}$ & $12.38 \mathrm{a}$ \\
\hline $\mathrm{TDM}(\mathrm{g})$ & $8.67 \mathrm{~b}$ & $12.05 \mathrm{~b}$ & $10.71 \mathrm{~b}$ & $15.37 \mathrm{a}$ & $16.20 \mathrm{a}$ \\
\hline DQI & $0.93 \mathrm{~b}$ & $1.30 \mathrm{a}$ & $1.23 \mathrm{a}$ & $1.36 \mathrm{a}$ & $1.57 \mathrm{a}$ \\
\hline
\end{tabular}

Where: SD: stem diameter; PH: plant height; NL: number of leaves; RL: root length; RDM: root dry mass; LA: leaf area; SDM: shoot dry mass; TDM: total dry mass; and DQI: Dickson's quality index. ns - No significant, * and ** significant by the $\mathrm{F}$ test at the level of 5 and $1 \%$ probability, respectively. Means followed by the same letter in the same line do not differ from each other by the Scott-Knott test $(\mathrm{p} \leq 0.05)$.

The estimates of the heritability in the broad sense $\left(\mathrm{H}^{2}\right)$ of the morphological characteristics evaluated varied from $45.38 \%$ (plant height) to $94.66 \%$ (stem diameter). The characters with high percentages of heritability were stem diameter $(94.66 \%)$, followed by leaf area (90.98\%), and total dry mass (89.79\%) (Table 2).

Table 2. Heritability in the broad sense $\left(\mathrm{H}^{2}\right)$, coefficient of genetic variation $(\mathrm{CVg})$, and the relationship between the coefficient of genetic variation and the coefficient of experimental variation $(\mathrm{GVg} / \mathrm{Cve})$ in morphological characteristics of guanandi seedlings from four municipalities of the State of Tocantins and one from the State of São Paulo. Gurupi - TO. 2018.

\begin{tabular}{c|c|c|c|c|c|c|c|c|c}
\hline Characteristics & SD $(\mathbf{m m})$ & PH $(\mathbf{c m})$ & NL & RL $(\mathbf{c m})$ & RDM $(\mathbf{g})$ & LA $\left(\mathbf{c m}^{2}\right)$ & SDM $(\mathbf{g})$ & TDM $(\mathbf{g})$ & DQI \\
\hline $\mathrm{H}^{2}$ & 94.66 & 45.38 & 60.82 & 69.31 & 60.73 & 90.98 & 87.95 & 89.79 & 84.40 \\
\hline $\mathrm{CVg}(\%)$ & 10.62 & 3.32 & 10.77 & 6.44 & 14.46 & 35.23 & 27.62 & 23.77 & 16.67 \\
\hline $\mathrm{GVg} / \mathrm{CVe}$ & 1.48 & 0.32 & 0.44 & 0.53 & 0.44 & 1.12 & 0.95 & 1.05 & 0.82 \\
\hline
\end{tabular}

Where: SD: stem diameter; PH: plant height; NL: number of leaves; RL: root length; RDM: root dry mass; LA: leaf area; SDM: shoot dry mass; TDM: total dry mass; and DQI: Dickson's quality index. 
Most of the analyzed characteristics presented a high coefficient of genetic variation $(\mathrm{CVg})$, with the highest values observed for the leaf area (35.23\%), shoot dry mass (27.62\%), and total dry mass (23.77\%). As well as the heritability in the broad sense $\left(\mathrm{H}^{2}\right)$ and the coefficient of genetic variation $(\mathrm{CVg})$, the relationship between the coefficient of genetic variation and the coefficient of experimental variation $(\mathrm{GVg} / \mathrm{CVe})$ also presented high values for stem diameter (1.48), leaf area (1.12), and total dry mass (1.05) (Table 2).

The genetic dissimilarity measures estimated from the generalized Mahalanobis distance (Table 3), present a wide range (from 1.52 to 42.26), indicating the presence of genetic variability between the areas. The seedlings from Formoso do Araguaia and São Paulo were more dissimilar (D2=42.26), followed by those from Formoso do Araguaia and Lagoa da Confusão (D2=37.08). The shortest distance was detected between the seedlings of Lagoa da Confusão and São Paulo (D2=1.52) (Table 3).

Table 3. Dissimilarity between municipalities of the State of Tocantins and São Paulo in guanandi seedlings in relation to nine morphological characteristics, based on the generalized distance of Mahalanobis ( $\left.\mathrm{D}^{2} \mathrm{ii}\right)$. Gurupi - TO. 2018.

\begin{tabular}{l|c|c|c|c|c}
\multicolumn{1}{c|}{ Municipalities } & $\mathbf{1}$ & $\mathbf{2}$ & $\mathbf{3}$ & $\mathbf{4}$ & $\mathbf{5}$ \\
\hline Formoso do Araguaia (1) & 0 & 14.16 & 12.15 & 37.08 & 42.26 \\
\hline Dueré (2) & & 0 & 5.63 & 23.44 & 26.29 \\
\hline Sandolândia (3) & & & 0 & 27.55 & 28.14 \\
\hline Lagoa da Confusão (4) & & & & 0 & 1.52 \\
\hline São Paulo (5) & & & & & 0 \\
\hline
\end{tabular}

Three groups of dissimilarities were formed based on morphological characteristics of the four municipalities of the State of Tocantins and one of São Paulo and using the grouping analysis by the Tocher method based on the Mahalanobis distance $\left(D_{i i}^{2}\right)$. Lagoa da Confusão and São Paulo were classified in group I, showing that these two areas are very similar genetically. In group II, there are Dueré and Sandolandia. Formoso do Araguaia was placed in group III, being isolated from the others.

Based on the relative contribution of each morphological characteristic to the genetic dissimilarity (Table 4), using the Singh (1981) criterion, the total dry mass, shoot dry mass, and root dry mass were the characteristics that most contributed to the morphological divergence with $49.37 \%, 44.28 \%$, and $5.41 \%$, respectively, while the other characteristics only contributed with $0.93 \%$ (Table 4 ).

Table 4. Relative contribution (\%) of the morphological characteristics to the genetic dissimilarity of guanandi seedlings from five municipalities, one being from the State of São Paulo and four from the State of Tocantins. Gurupi - TO. 2018.

\begin{tabular}{c|r|r|r|r|r|r|r|r|c}
\hline Characteristics & \multicolumn{1}{c|}{ TDM } & \multicolumn{1}{c|}{ SDM } & \multicolumn{1}{c|}{ RDM } & \multicolumn{1}{c|}{ DQI } & \multicolumn{1}{c|}{ SD } & \multicolumn{1}{c|}{ LA } & \multicolumn{1}{c|}{ RL } & PH & NL \\
\hline S.j. & 18884.35 & 16939.82 & 2069.49 & 150.25 & 146.87 & 35.39 & 10.09 & 7.58 & 7.00 \\
\hline Value (\%) & 49.37 & 44.28 & 5.41 & 0.39 & 0.38 & 0.09 & 0.03 & 0.02 & 0.02 \\
\hline
\end{tabular}

Where: TDM: total dry mass; SDM: shoot dry mass; RDM: root dry mass; DQI: Dickson's quality index; SD: stem diameter; LA: leaf area; RL: root length; PH: plant height, and NL: number of leaves. 
From the cluster analysis by the UPGMA method, the dendrogram was obtained (Figure 1). The cut-off point to find the groups was performed visually according to the long-distance jump or level change in the dendrogram (Figure 1).

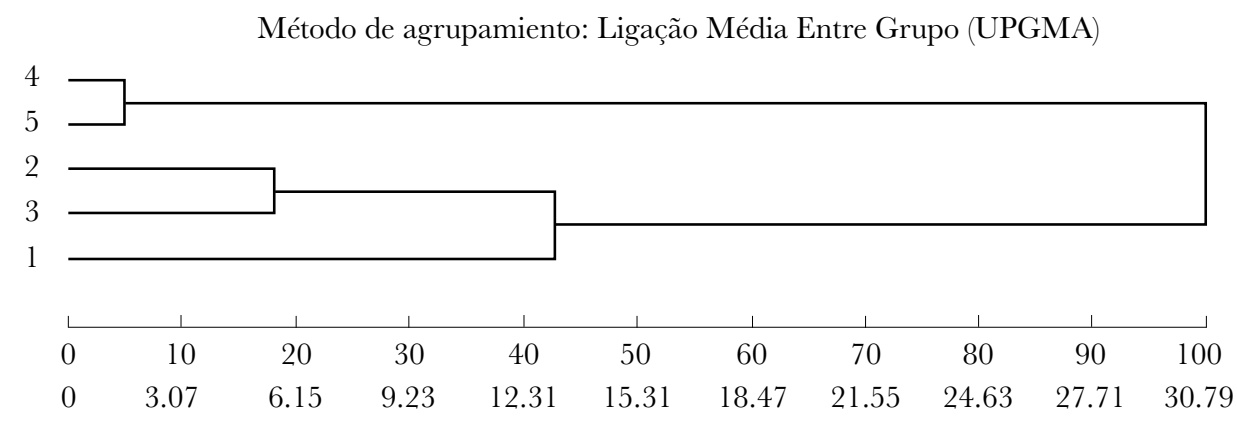

Figure 1. Dendrogram generated with the UPGMA method from the dissimilarities expressed by the Mahalanobis distance between the five guanandi areas obtained from the nine selected morphological characteristics. Gurupi - TO. 2018.

The lack of statistical differences between the areas may be due to the climatic and hydric similarities of the two states (Tocantins and São Paulo), which is confirmed by Wrege et al. (2017), presenting the favorable regions for the commercial production of guanandi. Other authors reported significant environmental variations for root length, such as Oliveira et al. (2006) studying the genetic variation of Baru (Dipteryx alata) progenies and Reis et al. (2006) analyzing clones of Eucalyptus sp. using root-related characteristics.

Variations in the root-related characteristics may be related to the growth and development capacity of the species. In this sense, a widely developed root system may result in a more vigorous seedling with greater chances of survival in environments with few nutrients and water.

The Dickson quality index considers the solidity and balance of the biomass distribution of the seedling, assessing the results of the important attributes in the quality evaluation. This index is widely employed by researchers in seedlings of forest species (Gomes $e t$ al. 2003). Thus, the higher the DQI, the higher the seedling quality, i.e., the better its development in the field.

According to Cruz (2005), the broad heritability values can vary from 0 to $100 \%$, considering high when the values obtained are greater than $40 \%$. The characteristics studied present a high heritability in the broad sense. The heritability for root length (69.31\%) was lower than that found by Oliveira et al. (2006) for Baru (D. alata), which obtained heritability values of $84.01 \%$ in plant evaluations in the seedling phase.

As stated by Falconer (1987), quantitative characteristics are highly influenced by the environment, and the lower the environmental effect on the genotype, the greater the heritability. Heritability is represented by the fraction of the genetically controlled characteristic when the heritability coefficients are high. Based on these criteria, high heritability coefficients, even in a broad sense, indicate an excellent possibility of success in the selection process. 
According to Costa et al. (2011), the greater the existing genetic variation, the greater the chances of genetic gains throughout the breeding program. GVg is considered an important parameter to understand the genetic structure of a population since it presents the amount of variation between the progeny in relation to the mean of the trait under study (Baleroni et al., 2003). Based on this information, it can be affirmed that the total dry mass, the shoot dry mass, and the leaf area are the characteristics that present possibilities of genetic gains in the selection programs.

According to a survey carried out by Aguiar (2004) on the heritability and the coefficient of genetic variation of the height and diameter of native tree species of Brazil, it can be observed that the estimates of heritability and coefficient of genetic variation of this work are representative and exceed the intervals observed by various authors, especially concerning the coefficient of genetic variation.

On the report of Vencovsky and Barriga (1992), when the $\mathrm{CVg} / \mathrm{CVe}$ ratio obtains a value equal to or greater than the unity, it indicates that it is possible to obtain representative genetic gain in the breeding process. In this way, the results found confirm the possibility of selection for these characteristics with good expectations of gain. Further experimental investigation should be performed to assess the association of these characteristics with those of importance in terms of the final product of the species.

In this work, variability was only considered between areas, with the need for future studies with a greater number of mother trees per region and characterization of genetic variability within populations. In addition to the incorporation of a greater number of morphological, botanical, and agronomic characteristics allied to molecular techniques. Thus, more complete results will be obtained on the genetic diversity of the guanandi populations of the State of Tocantins.

Guanandi studies are very few and even more those that examine the genetic divergences. The few available studies are with molecular markers (Reis et al., 2009). There are a spare number of works that have been reported on the study of the species with morphological data since these are important for the characterization of accessions in germplasm banks.

The formation of groups shows the variability between the areas, verified in the analysis of variance. The different municipalities were in the same dissimilarity group. Siqueira $e t$ al. (1993) and Carvalho (1994) suggest as an explanation for this minimal diversity among the progeny of the different areas that their origins are from the same ancestral population, or even that these materials may have suffered an anthropogenic action, dispersal of fruits through animals, and cross-pollination.

In the case of seedlings from São Paulo, which is from another state, the similarity with the seedlings from Lagoa da Confusão may be related to environmental factors and adaptability, as the seedlings were planted under the same conditions.

Pasqual et al. (2012) observed variability between the morphological characteristics in 16 genotypes of Bacuri (Platonia insignis Mart.) that compose the germplasm collection in the Empresa Brasileira de Pesquisa Agropecuaria (Embrapa) Middle-North, and using the same method they reported the formation of five groups. 
The characteristics total dry mass $(49.37 \%)$ and the shoot dry mass $(44.28 \%)$ were the most efficient to explain the dissimilarity between the progeny and should be prioritized in the selection of parents in the conservation programs and future improvements of the species, when seedling phase studies were considered.

Employing the UPGMA method it was possible to form two different groups, which were almost identical to the groups formed by the Tocher method, except for the municipality of Formoso do Araguaia (1) which was in an isolated group, and in this method, it remained grouped with Dueré (2) and Sandolandia (3) in group II. The most divergent progeny were São Paulo and Formoso do Araguaia, and the most similar were Lagoa da Confusão and São Paulo, reinforcing what was described in the dissimilarity matrix by genetic distance and in Tocher's method.

The optimization methods Tocher and UPGMA are normally used concomitantly to complete the results and help to better distinguish the clusters formed. The use of more grouping methods due to the differences in the hierarchy, optimization, and ordering of the groups allows complementary classification, as each technique employs different criteria, and avoids the adoption of erroneous inferences in the assignment. of elements, within a certain sub-group of genotypes (Arriel et al., 2006).

The relatively low cost of morphological characterization makes it an interesting tool for research in species conservation programs, material collection programs for germplasm banks, production of seedlings for reforestation, in addition to strengthening subsidies for future breeding programs of the species.

\section{GONGLUSIONS}

There is morphological variability in the seedlings of C. brasiliense Cambess among the five municipalities with $67 \%$ of the evaluated characteristics. The characteristics total dry mass, shoot dry mass, and root dry mass contributed the most to the genetic divergence between the municipalities. The results suggest that variations in morphological characteristics can be used as a tool for genetic studies of $C$. brasiliense Cambess progenies according to their similarities and/or differences. The state of Tocantins is suitable to produce C. brasiliense Cambess for commercial purposes and for the development of conservation and breeding programs for the species.

\section{REFERENGES}

Arriel, N.H.C.; Mauro, A.O.D.; Mauro, S.M.Z.D.; Bakke, O.A.; Unêda-Trevisoli, S.H.; Costa, M.M.; Capeloto, A.; Corrado, A.R. (2006). Técnicas multivariadas na determinação da diversidade genética em gergelim usando marcadores RAPD. Pesquisa Agropecuária Brasileira, Brasília, 41(5):801-809. Doi: 10.1590/S0100-204X2006000500012

Aguiar, A.V. (2004). Emprego de parâmetros moleculares equantitativos na conservação e melhoramento de Eugenia dysenterica. 186p. Tesis de Doctorado en Genética y Mejoramiento de Plantas. Universidade Federal de Goiás, Goiânia.

Baleroni, G.R.S.; Alves, P.F.; Santos, E.B.R.; Cambuim, J.; Andrade, J.A.C.; Morais, M.L.T. (2003). Variação genética em populações naturais de aroeira em dois sistemas de plantio. Revista Instituto Florestal, São Paulo, 15(2):125-136. Doi: 10.1590/S0100-67622006000300001

Botrel, M.C.G.; Souza, A.M.; Carvalho, D.; Pinto, S.I.C.; Moura, M.C.O.; Estopa, R.A. (2006). Caracterização genética de Calophyllum brasiliense Camb. em duaspopulações de mata ciliar. Revista Árvore, Viçosa, 30(5):821-827.

Carvalho, P.E.R. (1994). Espécies florestais brasileiras: recomendações silviculturais, potencialidade e uso da madeira. (pp.199-204). Colombo: Embrapa-CNPF/SPI.

Carvalho, P.E.R. (2003). Espécies arbóreas brasileiras. Brasília, DF: Embrapa Informação Tecnológica. (pp. 1039). Colombo: Embrapa Florestas. 
Costa, R.B.; Almeida, E.V.; Kaiser, P.; Azevedo, L.P.A.; Martinez, D. T.; Tsukamoto-Filho, A.A. (2011). Avaliação genética em progênies de Myracrodruon urundeuva Fr. All. na região do Pantanal, estado do Mato Grosso. Revista Brasileira de Ciências Agrárias, Pernambuco, 6(4):685-693.

Cruz, C. D. (2005). Princípios da genética quantitativa. Viçosa, (No. 575.1). Minas Gerais: Universidade Federal de Viçosa, 394p.

Cruz, C.D. (2016). Genes Software - extended and integrated with the R, Matlab and Selegen. Acta Scientiarum. 38(4):547-552. Doi: 10.4025/ actasciagron.v38i4.32629

Falconer, D.S. (1987). Introdução à genética quantitativa. 279 p. Tradução de Martinho de Almeida e Silva e José Carlos Silva. Viçosa, Minas Gerais: Universidade Federal de Viçosa.

Ferreira, D.F. (2019). SISVAR: Computer analysis system to fixed effects split plot type designs. Revista Brasileira de Biometría, 37(4): 529-535. Doi: $10.28951 /$ rbb.v37i4.450

Gomes, J.M.; Couto, L.; Leite, H.G.; Xavier, A.; Garcia, S.L.R. (2003). Crescimento de mudas de Eucalyptus grandis em diferentes tamanhos de tubetes e fertilização N-P-K. Revista Árvore, Viçosa, 27(2):1 13-127. Doi: 10.1590/S0100-67622003000200001

Köppen, W. (1948). Climatologia: con un estudio de los climas de la tierra. Fondo de Cultura Econômica. México. 479p.

Oliveira, E.M.; Mesquita, A.C.; Freitas, R.B. (2002). Análise de crescimento de plantas. Departamento de Biologia, Universidade Federal de Lavras. 9p.

Oliveira, A.N.; Silva, A.C.; Rosado, S.C.S.; Rodrigues, E.A.C. (2006). Variações genéticas para características do sistema radicular de mudas de baru (Dipteryx alata Vog.). Revista Árvore, Viçosa, 30(6):905-909. Doi: 10.1590/S0100-67622006000600005

Pasqual, M.; Chagas, E. A.; Soares, J. D. R.; Rodrigues, F. A. (2012). Tissue culture techniques for native Amazonian fruit trees. In A. Leva, \& L. M. R. Rinaldi (Eds.), Recent advances in plant in vitro culture (p. 220). Intech. DOI: 10.5772/52211

Rao, R.C. (1952). Advanced statistical methods in biometric research. New York: John Wiley, 390 p.

Reis, G.G; Reis, M.G.F.; Fontan, I.C.I.; Monte, M.A.; Gomes, A.N.; Oliveira, C.H.R. (2006). Crescimento de raízes e da parte aérea de clones de híbridos Eucalyptus grandis x Eucalyptus urophylla e de Eucalyptus camaldulensis x Eucalyptus spp. Submetidos a dois regimes de irrigação no campo. Revista Árvore, 30(6):921-931. Doi: 10.1590/S0100-67622006000600007

Reis, G.A.F.; Souza, A.M.; Mendonça, E.G.; Gonçalvez, F.R.; Melo, R.M.G.; Carvalho, D. (2009). Diversidade e estrutura genética espacial de Calophyllum brasiliense CAMB. (Clusiaceae) em uma floresta paludosa. Revista Árvore, Viçosa, 33(2):265-275.

Scott, A.; knott, M. (1974). Cluster-analysis method for grouping means in analysis of variance. Biometrics, Washington D.C., 30(3):507-512. DOI: $10.2307 / 2529204$

Schorn, L.A.; Formento, S. (2003). Silvicultura II: produção de mudas florestais. Universidade Regional de Blumenau, Centro de Ciências Tecnológicas, Departamento de Engenharia Florestal. 23-24 p.

Singh, D. (1981). The relative importance of characters affecting genetic divergence. The Indian Journal of Genetic and Plant Breeding, New Dehli, 41 (2):237-245.

Siqueira, G.M.F.; Nogueira, J.C.B.; Kageyama, P.Y. (1993). Conservação dos recursos genéticos ex-situ do cumbaru Dipteryx alata Vog.Leguminosae. Revista Instituto Florestal, São Paulo, 5:231-243.

Soerianegara, I.; Lemmens, R.H.M.J. (1993). Calophyllum L. Plant Resources of South-East Asia, 5(1):114-119.

Tropical flora reflorestadora. (2014). Calophyllum brasiliense e suas características. Disponible en: <http://www.tropicalflora.com.br/pt/ reflorestamento/og.jsp>

Vencovsky, R.; Barriga, P. (1992). Genética biométrica no fitomelhoramento. Ribeirão Preto. Sociedade Brasileira de Genética, 1992:496p.

Wrege, M.; Fritzsons, E.; Kalil-Filho, A.N.; Aguiar, A.V. (2017). Regiões com potencial climático para plantio comercial do guanandi no Brasil. Embrapa Florestas-Artigo em periódico indexado (ALICE). 